doi: $10.19090 / \mathrm{i} .2021 .32 .36-54$

UDC: $347.65 / .68(4)$

ISTRAŽIVANJA

JOURNAL OF HISTORICAL RESEARCHES

32 (2021)

\author{
ORIGINAL SCIENTIFIC PAPER \\ Received: 9 May 2021 \\ Accepted: 28 June 2021
}

IVANA KOMATINA

The Institute of History, Belgrade

ivana.komatina@iib.ac.rs

PREDRAG KOMATINA

The Institute for Byzantine Studies, SASA

predrag.komatina@vi.sanu.ac.rs

\title{
FAMILY PATRIMONY AND THE LEGACY OF THE FIRST-BORN SON. SOME EXAMPLES FROM EUROPEAN MONARCHIES IN THE $11^{\text {th }}-12^{\text {th }}$ CENTURIES
}

\begin{abstract}
The paper examines the concept of family patrimony on the example of three medieval monarchies between the mid-1 $11^{\text {th }}$ and late $12^{\text {th }}$ centuries. Though far away from one another, Spain, England and Serbia witnessed almost identical political circumstances when the ruler passed the throne to a younger son, bypassing the first-born son, thereby also directly infringing the right of primogeniture. As a rule, such decision resulted in years-long conflicts among the brothers. However, the common denominator in all three cases is that family patrimony was entrusted to the eldest son regardless of the fact that he was not an heir to the throne, which implies that it was his inalienable right.

Keywords: family patrimony, dedovina, Fernando I, William I the Conqueror, Stefan Nemanja, medieval monarchy, feudal society.
\end{abstract}

$\mathrm{E}$ xamples of the same phenomenon can be seen in three entirely different parts of Europe, far away from one another, between the mid- $11^{\text {th }}$ and late $12^{\text {th }}$ centuries. Three rulers had three sons and each of them, by the very end of his rule, left the throne to his middle son, bypassing the eldest, to whom he left a part of his legacy. These were significant rulers, whose rule brought about significant changes in the history of their countries. Fernando I (1037-1065), King of León and Castile, reunited Castile with the Kingdom of León and initiated the Christian Reconquista of the Iberian Peninsula from a dead point where it had languished for more than a century. With the victory at the Battle of Hastings in 1066, William I the Conqueror (1066-1087), King of England and Duke of Normandy and his Norman knights, ended the Anglo-Saxon period in the history of England and initiated an entirely new epoch in the history of that country and the British Isles as a whole, which was strongly marked by the Norman feudal legacy. Finally, Grand Župan Stefan Nemanja (1166-1196), ruler of the Serbian lands, laid a strong foundation for the Serbian medieval kingdom with his steadfast 
struggle against the supreme authority of the Byzantine Emperor.

Just before his death in 1065, Fernando I decided to leave the royal throne of León to his middle son Alfonso VI (1065-1072, 1072-1109). He left Castile to his eldest son Sancho II (1065-1072) and Galicia to his youngest son García (1065-1071). Before his death in 1087, William the Conqueror bequeathed the English Kingdom to his middle son William II (1087-1100). He left the Duchy of Normandy to his eldest son Robert and 5000 pounds in silver to his youngest son Henry. A century later, in Serbia, Grand župan Stefan Nemanja renounced the throne in favour of his middle son Stefan (1196-1223), ${ }^{1}$ and left to his eldest son Vukan 'sufficient lands' - Dioclea, Dalmatia, Travunia, Toplica and Hvosno, whereafter he took monastic vows and became Monk Simeon, joining his youngest son, Monk Sava, on Mount Athos. Each of these rulers had reasons for leaving their thrones to their middle sons, and each of them substantiated their decisions. What arouses most interest is the legacy that each of them left to their eldest sons, who, despite the advantage of being first-born, did not get the main award. These three cases have some parallels, which may indicate common backgrounds for each of them.

\section{Spain}

Fernando I Sánchez was the son of Sancho Garcés III (1004-1035), the king of Pamplona (Navarra) and the most powerful among all Christian and Muslim rulers in the Iberian Peninsula at the time. During his rule, Sancho Garcés conquered Ribagorza (1017), Castile (1028) and León (1034). Before his death, he divided the kingdom among his sons. He left Pamplona and the royal crown to his eldest son García Sánchez III (1035-1054). He left Castile, which he possessed in his wife's right, to his second-born son Fernando, whom had he made a count there in 1029. The third son Gonzalo was given Ribagorza and Sobrarbe, and his illegitimate son Ramiro (1035-1063) received Aragón, 'a far-flung portion of his kingdom'. ${ }^{2}$

Fernando did not inherit a royal title from his father, but the title of a count, and, at the beginning, he was subjugated to his brother García as the King of Pamplona (Navarra), just as he had been subordinate to his father. ${ }^{3}$ However, being married to Sancha, the sister of the then King of León Vermudo III (1028-1037), already in 1037 he defeated his wife's brother at the Battle of Tamarón. He captured León and was crowned there the following year as King of León, whereafter he ruled as King of León and Castile, ${ }^{4}$ thus reuniting Castile with the

For the new date of the death of Stefan Nemanjić, cf. Bubalo 2020: 99-116.

About the division of the Kingdom of Sancho Garcés III, cf. Historia silense 1921: 63-64; Pérez de Urbel 1954: 3-26; Ubieto Arteta 1960: 5-56; Reilly 1988: 7-8; Sánchez Candeira 1999: 91-101; Martínez Díez 2007: $175-183$.

3 According to Historia silense, at the time of the rule of King Vermudo III of León (1028-1037), the Pisuerga River was the border between León and Cantabria, i.e. Pamplona, which means that Castile belonged to Pamplona (Navarra) at the time, Historia silense 1921: 64-65. About Fernando as a count in the 1029-1037 period, cf. Ubieto Arteta 1960: 35-38; Sánchez Candeira 1999: 67-83, 105-109; Martínez Diez 2005: 681 sq.

4 'Tunc Fredenandus Rex, congregato magno exercitu, pugnauit cum cognato suo Rege Ueremudo in Ualle Tamaron, et ibi mortuus fuit Rex Veremudus... His peractis prefatus Rex Fredenandus uenit at obsedit Legionem, et post paucos dies cepit eam, et intrauit cum multitudine maxima militum, et accepit ibi coronam, et factus est Rex in Regno Legioni et Castella...,' Crónica del obispo don Pelayo 1924: 72-73; 'Interea ex vinculo unitatis et dilectionis oritur inter Fredinandum et Veremudum cognatum suum altra discordia... 
Kingdom of León, which also included Galicia. ${ }^{5}$ Although such a custom did not exist in León according to the norms of Visigothic law applied there, following the example of his father, at the council held in León in late 1063, on the occasion of the official translation of the relics of St Isidore from Seville to León, Fernando decided to divide the Kingdom among his three sons, Sancho, Alfonso and García, designating which parts would belong to them after his death. ${ }^{6}$

According to Historia silense (or Legionense) from the early $12^{\text {th }}$ century: 'King Fernando... decided to divide his kingdom among his sons. He placed Alfonso, whom he loved most of all his children, at the head of the Gothic fields and entrusted him with the rule of the entire Kingdom of León. He designated Sancho, his first-born son, as the King of Castile. Apart from this, he granted Galicia to his younger son García' ${ }^{7}$ According to the Chronicle of Bishop Pelagius of Oviedo from the same period, King Fernando, 'before he died, divided his kingdom among his sons as follows. He gave master Sancho, from the Pisuerga river, the entire Castile, Nájera and Pamplona, with all the appertaining royal rights. He ceded León to master Alfonso along the Pisuerga River, the entire Asturias and Trasmiera, up to the River Oue, Astorica, Campos, Zamoram... He gave to master García the entire Galicia, together with entire Portugal'. ${ }^{8}$ In Chronicon Compostellanum, the division is described similarly: 'Fernando... divided the kingdom among his three sons, Sancho, Alfonso and García. He gave the entirety of Castile to his first-born son Sancho, with Asturia sancte Iuliane... He entrusted León with Asturia to Alfonso, and to his lastborn son García he gave Galicia with Portugal as his personal patrimony'.

These sources emphasise that Fernando 'entrusted the entire Kingdom of León' to his middle son Alfonso VI because 'he loved him most of all children' (quem prae omnibus liberis carum habebat). Soon after his father's death, Alfonso was crowned king in the Cathedral of León. ${ }^{10}$ On the other hand, it is underscored that he 'designated Sancho II his first-born son as the king in Castile' (Constituit quoque Santium primogenitum filium suum super Castellam

Fredinandus deinceps extincto Veremudo, a finibus Gallecie veniens obsedit Legionem, et omne regnum sue ditioni degitu. Era MLXXVI, X kalendas Iulii consecratus dominus Fredinandus in ecclesia beate Marie Legionensis, et unctus in regem a venerande memorie Servando eiusdem ecclesie catholico episcopo...,' Historia silense 1921: 65-68; Ubieto Arteta 1960: 38-39; Sánchez Candeira 1999: 109-114.

5 About the rule of Fernando I, cf. Reilly 1988: 8-13; Sánchez Candeira 1999: 115-225.

6 Cf. Reilly 1988: 14-17; Sánchez Candeira 1999: 225-231; Gonzalez Minguez 2002: 84-87.

7 'Fernandus rex... regnum suum filiis suis dividere placuit. Aldefonsum itaque, quem prae omnibus liberis carum habebat, campis Gothorum praefecit, atque omne Legionensium regnum suae ditioni mancapavit. Constituit quoque Santium primogenitum filium suum super Castellam Regem. Necnon, et iuniorem Garsiam Galleciae pertulit,' Historia silense 1921: 87.

8 'Et ante quam moreretur diuisit Regnum suum sic filiis suis. Dedit dompno Sancio per flumen Pisorga tota Castella, Nagara, Pampiloniam cum omnibus regalibus sibi pertinentibus. Dedit dompno Adefonso Leogionem per flumen Pisorga, totas Asturias et Trasmera, usque in flumine Oue, Astorica, Campos, Zamoram, Campo de Tauro, Berizo, usque uilla Ux, in monte Ezebrero ad illa Ulze. Dedit Domno Garsea totam Galleciam, una cum toto Portugale,' Crónica del obispo don Pelayo 1924: 75-76.

9 'Fredenandus annos XXVII regnauit, qui in uita sua cum uxore sua nomine Sancia, regis Adefonsi filia, ad quam regnum pertinebat, ipsum regnum inter tres filios eius, Sancium scilicet, Adefonsum, Garseam diuisit. Et Sancio primogenito totam Castellam cum Asturia sancte Iuliane... in proprium reddit; Adefonso uero Legionem cum Asturiis... tribuit; Garsea autem natu minori Galleciam cum Portugalia in propriam hereditatem concessit...,' Chronicon Compostellanum 1983: 79.

Carriedo Tejedo 2003: 13-30. 
Regem), and that he gave to him 'from the Pisuerga river, the entire Castile, Nájera and Pamplona, with all the appertaining royal rights' (cum omnibus regalibus sibi pertinentibus) ${ }^{11}$ which means that he made him king in the land he entrusted him with, which is how Castile became a separate kingdom for the first time. ${ }^{12}$ The precedence thus given to the second-born son was obvious, not only because he inherited the older and more important royal throne, which had brought a royal crown to his father, and thus became his father's immediate successor, but also because his share was much larger and richer than the share of his brothers. ${ }^{13}$ However, Fernando's decision triggered a long civil and fratricidal war. Being the eldest, Sancho believed he should be their father's sole successor and should rule their father's entire kingdom as the King of León. He therefore went to war against his brothers and took Galicia in 1071 and León in 1072, and was crowned king in León. After perishing under the walls of Zamora, in October of the same year, his younger brother Alfonso VI took over his kingdom and became the ruler of León, Castile, and Galicia, their father's entire former kingdom. ${ }^{14}$

\section{England}

Less than a year after King Fernando I's death, an event of momentous importance for western European history took place. On October 14, 1066 at the Battle of Hastings, William the Bastard, Duke of Normandy since 1035, defeated the last Anglo-Saxon King

11 About the relationship between the Chronicle of Bishop Pelagius and Historia silense, cf. Alonso Álvarez (décembre 2012) Publicado el 20 noviembre 2013, consultado el 28 abril 2021. URL: http://journals.openedition.org/e-spania/21586; DOI: https://doi.org/10.4000/e-spania.21586

12 Prevalent up until recently in Spanish historiography was the traditional belief - based on data from later chronicles written in the mid- $13^{\text {th }}$ century at the time of Alfonso X the Wise (1252-1284) - that Fernando I, immediately after the death of his father Sancho Garcés III of Navarra in 1035, became the first king of Castile, and that in 1037-1038 he only captured León and joined it to his Castilian kingdom. However, recent research has unambiguously shown that he inherited from his father only the title of a count and that he, at the beginning, as the Count of Castile, was subordinate to his older brother García Sánchez III as the King of Navarra, as well as that he became a king 'in León and Castile' only after conquering León and being crowned king in the cathedral of León. In other words, Castile, which he ruled until 1037, was not a kingdom; he obtained a royal title only after the capture of León and it was related to León, cf. Ubieto Arteta 1960: 35-38; Sánchez Candeira 1999: 105-225; Martínez Diez 2005: 713, so it was only his son Sancho II who became the first King of Castile, which would, in fact, be the meaning of the source data that his father 'designated him as the King of Castile', 'with all the appertaining royal rights'.

13 Reilly 1988: 14-19, 52-57; Sánchez Candeira 1999: 230-231; Martínez Díez 2003: 16-19.

14 'Post hec Sancius Rex cepit dimicare aduersus fratrem suum Adefonsum Regum, ut caperet regnum eius... Tunc Sancius rex cepit regnum fratris sui Adefonsi regis, et imposuit sibi in Legione coronam... Regnauit autem annos VI et interfectus est extra muros Zemore, quam obsederat... Quo audito, Adefonsus rex uenit uelociter et accepit regnum fratris sui Sancii regis et regnum suum, quod perdiderat...,' Crónica del obispo don Pelayo 1924: 77-79; 'Regno ita diviso et unoquoque fratrum suam partem iam tenente, Sancius primogenitus frater cum duobus fratribus singulis vicibus pugnavit et bello captos alterum, scilicet Adefonsum, Toletum, alterum vero, scilicet Garseam, Ispalim cum omnibus militibus in exilium abire permisit. Regno ita acquisito et suo iuri subiugato... Scemuram inauspicato obsedit. Dum enim ille in castris suis moraretur, quidem miles Scemurensium civium consilio et machinatione ab urbe exivit et eum... proditorie interfecit. Regnavit autem menses VIII et XXV dies. Eo mortuo, Adefonsus eius frater, qui ab illo in exillium Toletum expulsus fuerat, inde reddit et fere totum regnum patris sui sua strenuitate acquisivit...,' Chronicon Compostellanum 1983: 79-81. Cf. Reilly 1988: 14 67; Gonzalez Minguez 2002: 87-98; Vivancos Gómez 2014: 41-55; Bergqvist 2018: 64-86. 
Harold, conquered England, and was crowned King of England on Christmas Day of that year. William I (1066-1087), for this reason remembered as the Conqueror, then ruled both countries, England and Normandy, for twenty years, during which he had to consolidate his rule in England with harsh and unpopular measures. ${ }^{15}$

Before his death in 1087, William the Conqueror gathered his friends and his sons William and Henry in Rouen to inform them of his decision 'de regni ordinatione,' while 'his son Robert, who was older by birth and had risen up many times against his father...fled to the French king'. ${ }^{16}$ In his bequest, recorded several decades later in The Ecclesiastical History by the monk Orderic Vitalis and shaped by his pen but with much credibility, ${ }^{17}$ William first mentions his achievements and conquests in order to describe the estates he left to his successors. ${ }^{18}$ In the continuation, he states: 'I left the Duchy of Normandy... to my son Robert, because he is the first-born (Ducatum Normanniae... Roberto filio meo concessi, quia primogenitus est...). He had already received hominium (homage) from almost all nobles of this land. But I indubitably know that a land subjugated to his lordship would be very miserable. He is haughty and light-minded... ${ }^{19} \mathrm{I}$ leave no one as the successor to the English Kingdom. I leave it to the Eternal Creator, to whom I belong and who holds everything in his hand. Because I did not possess such dignity through hereditary right, but I seized it from fickle King Harold in a horrendous battle, by spilling much human blood, and I subjugated it to my lordship after killing or banishing his supporters... I dare not deliver the sceptre of that kingdom, which I obtained through so many sins, to anyone, apart from God himself, so as to preclude even worse circumstances from occurring after my death. ${ }^{20}$ I believe that my son William, who has always been committed to me from an early age and has, according to his power, always gladly subjected himself to me in everything, is sufficiently worthy in God's spirit and that he will happily shine on the kingdom's throne, if this is God's will'. ${ }^{21}$ When asked by his youngest son Henry, 'What do you leave to me, father?' the king answered that he would leave him 5000 pounds in silver from his treasury. ${ }^{22}$

15 About the Battle of Hastings and the rule of William the Conqueror in England, cf. Carpenter 2004: 61-105; Bates 2016: 211-481.

16 Ordericus Vitalis III 1845: 228.

17 Cf. Garnett 2007: 136-185; Aird 2008: 99-109; Bates 2016: 483 sq. There is also another, significantly shorter outline of William's decision on succession, in the manuscript De obitu Willelmi, from the first half of the $12^{\text {th }}$ century, added to the text Gesta Normannorum Ducum by William of Jumièges, which only states that William the Conqueror left the crown, sword and sceptre to his son William ('Et Willelmo quidem suo filio coronam, ensem, sceptrum auro gemmisque redimitum, habendum permisit'), but it has been proven that this statement was taken over in entirety from the description of bequest of the King of Franks Louis the Pious (814-840) for his youngest son Charles the Bald in Vita Hludowici imperatoris. It has also been indicated that Orderic's description of events, although written down several decades later and burdened by the memory of later events, is trustworthy, cf. English 1991: 222-227.

18 Ordericus Vitalis III 1845: 228-242.

19 Ordericus Vitalis III 1845: 242.

20 Ordericus Vitalis III 1845: 242-243.

Ordericus Vitalis III 1845: 243.

22 Anticipating the later events and arrival of Henry I (1100-1135) to the English throne and his taking over of Normandy in 1106, Orderic Vitalis notes that the young prince answered to his father that he did not need wealth as he did not have a place to live, while the king told him to be patient as older brothers had precedence over him: 'Robert will have Normandy, and William England, and you, in your own time, will have all the honour 
William's decision was not without consequences. As the eldest, Robert believed he should inherit both of his father's territories, while the Norman barons in England who also had estates in Normandy found themselves in an inauspicious position because, in the event of a conflict among the brothers, they would have to support one of them and thus lose the favour of the other. They therefore believed that it was best if one king again ruled both territories, which is why they supported Robert's pretensions and rebelled against William II. However, despite this, Robert could not overpower his brother, and after an unsuccessful mutiny in 1088, he had to recognise his younger brother as King of England and satisfy himself with the title of Duke of Normandy. ${ }^{23}$

As it can be seen, Fernando I and William the Conqueror left their royal thrones, the former in León and the latter in England, to their middle sons, Alfonso VI and William II. In both cases, it was the land to which they did not have a hereditary right. Fernando began his rule of León based on the right of his wife, Queen Sancha, after he defeated and killed her brother Vermudo III at the Battle of Tamarón in 1037 and conquered León. William seized the English Kingdom by defeating the last Anglo-Saxon King Harold at the bloody Battle of Hastings in 1066 and had to consolidate his authority there with a firm hand and drastic measures throughout his rule, which he also noted in his bequest. In both cases, it is highlighted that the chosen successor enjoyed more sympathy from their father in comparison to their brothers, which was used as justification for inheriting his father's throne instead of his older brother. It is thus stated of Alfonso VI that his father 'loved him most of all children, ${ }^{24}$ while of William II it is said that he "was committed from his early age' to his father and that he 'was always gladly subjugated to him in everything'. ${ }^{25}$ This did not necessarily mean mistrust towards the first-born son, although it is known that William the Conqueror and his eldest son Robert were not on good terms as far back as Robert's early youth, because he often mutinied against his father and roamed with his knights between Normandy, Flanders and the throne of the French king. William's negative attitude towards his first-born son is also tellingly delineated in his bequest. ${ }^{26}$

However, what is apparent in both cases is that although they did not leave their royal thrones to their eldest sons, both Fernando I and William I left them their family patrimony, i.e. Castile and Normandy, respectively. The author of Historia silense emphasises that King Fernando I designated his 'first-born son' (primogenitum filium suum) Sancho as King of Castile, while his contemporary, the author of Chronicon Compostellanum, highlights that he 'gave to his first-born son Sancho (Sancio primogenito) the entirety of Castile in possession.' According to Orderic Vitalis, William the Conqueror explicitly emphasised in his bequest that he left the Duchy of Normandy to Robert because 'he is the first-born' (quia

that I possess, and you will surpass your brothers with your wealth and power', Ordericus Vitalis III 1845: 243.

23 Carpenter 2004: 125-129; Aird 2008: 109-152.

24 There are scarce data about the attitude of Fernando I towards his sons and about their activity during their father's life, cf. Martínez Díez 2003: 9-16.

25 About the attitude of William the Conqueror towards his younger sons, cf. Garnett 2007: 172-174.

26 Disagreements between Robert and his father dated back to 1077-1078, cf. Garnett 2007: 153-171; Aird 2008: 78-98; Bates 2016: 373-450. 
primogenitus est), despite being confident that no country would be fortunate under his rule. So, in both cases there is an obvious link between family patrimony and the legacy of the first-born son. In the case of England and Normandy, this would be quite obvious as it may be concluded that William I simply followed the well-evidenced Norman legal concept that family patrimony (patrimonium) should belong to the eldest son undivided, while later acquisitions (aquisitio) could be given to younger sons as well. ${ }^{27}$ On the other hand, Fernando's decision to divide legacy among his sons was long-overshadowed in Spanish historiography by the traditional view of Castile as Fernando's primary kingdom and of León as a less important territory that had been conquered and joined with Castile, which is why his decision to leave Castile to his first-born son and León to his second-born son did not seem disputable in any respect. When researchers ascertained that Fernando had in fact given precedence to Alfonso over Sancho, the circumstance that he left Castile to the latter was explained by his following the Navarran legal norms according to which the patrimony of the ruling family should belong to the eldest son. ${ }^{28}$ The fact that Castile belonged to Fernando according to his mother's right rather than his father's does not change the fact that, since Navarra belonged to his eldest brother and thus remained outside his possession, Castile was Fernando's personal estate, which he inherited from his ancestors, while León with Galicia belonged to him only through his wife's right. That in Fernando's family Castile was considered family patrimony and, as such, the legacy of the first-born son, is also indicated by the fact that after Alfonso VI and his daughter Uracca (1109-1126) ruled a unified kingdom, her son Alfonso VII (1126-1157), when he decided before his death in 1157 to divide it again among his sons, bequeathed Castile and Toledo to his older son Sancho III (1157-1158) and León and Galicia to his younger son Fernando II (1157-1188). ${ }^{29}$

This all suggests that, according to the feudal law that had been shaped in western Europe up until then, family patrimony was considered the legacy of the first-born son. ${ }^{30}$ Moreover, it was preordained for him: William the Conqueror, even before his conquest of England, considered his eldest son Robert his successor in Normandy, ${ }^{31}$ and it is believed that from 1060, Sancho II resided in Castile and led the local knights. ${ }^{32}$ What can be further concluded from these examples is that the first-born son could not be deprived of family patrimony even if he, for some reason, was deprived of the main legacy in his father's territories. In other words, these examples testify to the understanding that, as an ancestral legacy, family patrimony had to belong to the eldest son regardless of any other circumstances, political or personal, accompanying the succession of his father.

27 Cf. Le Patourel 1971: 225-250; Holt 1972: 45-48; English 1991: 221-222; Carpenter 2004: 125; Garnett 2007: 136-185; Bates 2016: 483 sq.

28 Cf. Ubieto Arteta 1960: 35; Reilly 1988: 14-19; Sánchez Candeira 1999: 230-231; Gonzalez Minguez 2002: 83-86; Martínez Díez 2003: 16-19.

29 Ubieto Arteta 1960: 35; Linehan 2008: 7-8.

30 The issue of heredity of feudal estates and royal power was not regulated by clear legal provisions, but the stance towards it, just as many other aspects of feudal order, was shaped over time, in line with customs prevailing in a particular environment, which is why the concept of primogeniture can be discussed only conditionally, Blok 2012: 309-337, 594-608.

31 Holt 1972: 46; Davis 1980: 597-606; Garnett 2007: 153-164; Aird 2008: 60-76.

32 Gonzalez Minguez 2002: 85. 


\section{Serbia}

The last of the three examples is somewhat more distant in terms of time and space. It concerns events in south-eastern Europe at the end of the $12^{\text {th }}$ century, but we believe it can be explained in the same way. At the Diet of Ras on March 25, 1196, Grand Župan Stefan Nemanja renounced the Serbian throne and was tonsured as Monk Simeon. He left his throne to his middle son Stefan and a part of his domains to his eldest son Vukan. The circumstances in Serbian lands in terms of shaping the territorial framework of the country, which he divided among his sons, were somewhat more complex and were closely related to his decision, which is why they deserve a somewhat lengthier analysis.

In examining the issue of family patrimony on the example of the Serbian lands in the $11^{\text {th }}$ and $12^{\text {th }}$ centuries, we must focus on the earliest days of Stefan Nemanja. The founder of the Nemanjić dynasty was born in Dioclea (Zeta), where his father had also been born. In the Life of his father, his son and successor Stefan, later the first-crowned king, explicitly states that Nemanja's father, due to 'great turmoil' in 'this part of the Serbian land and Diocletia and Dalmatia and Travunia' was deprived of land by his brothers and fled from their mutiny (!) to the place of his birth - Dioclea, where his youngest son Stefan Nemanja was born, most probably in $1113,{ }^{33}$ whom his son Stefan describes as having become 'the one who joined together the ruined lands of the fatherland'.$^{34}$

Nemanja's father Zavida was at one point deprived of land by his brothers, and he returned to his birthplace of Dioclea, which Stefan, when elsewhere describing Nemanja's later conquests, calls his 'true dedovina' (patrimony). ${ }^{35}$ When writing further about Nemanja's father, i.e. his grandfather, whose name he does not mention, Stefan states that he later returned to 'the ruling place', i.e. the grand župan's throne. ${ }^{36}$ It is assumed that the death of Grand Župan Uroš I enabled Zavida to move from Dioclea to continental Serbia most probably between 1129-1130 and 1134 and assume the grand župan's throne. ${ }^{37}$ Zavida could bestow his sons 'a part of the fatherland' at the time of his reign in Serbia (1130/1134-1143/1146) and only as grand župan. According to Stefan, his father Nemanja was an adolescent (aged between 15 and 22) when he received from his father 'a part of the fatherland,' which included 'Toplica, Ibar, Rasina and Reke', that is the eastern part of the then Serbian lands. ${ }^{38}$

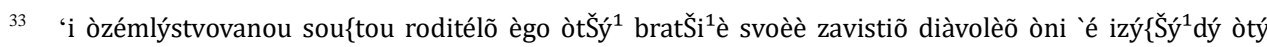
kramoli ihý vý mästo ro`dénià svoègo rékomoè diòklitià...', Stefan Prvovenčani 1999: 18; Komatina P. 2020: 18-19.

34 'sývýkoupitélà pogÿ İ\{imý stranamý òtŠý ${ }^{1}$ ýstvÿà ègo', Stefan Prvovenčani 1999: 18.

35 Describing Nemanja's conquests in the 1180 s, Stefan the First-Crowned states that the then Serbian grand župan returned 'Diòklitiõ `é i dali̇maciõ òtŠý' ${ }^{1}$ ýstvo i ro`déniè svoè istovouõ dädinou svoõ', Stefan Prvovenčani 1999: 38; Ćirković 2000: 25.

36 Stefan Prvovenčani 1999: 18. Prevalent opinion in science is that Nemanja's father Zavida was not a grand župan as he is not mentioned with such title in the well-known inscription on the lintel of the church of St Peter and Paul in Bijelo Polje, the endowment of Zavida's son and Nemanja's older brother Miroslav, Marković 2012: 21-40.

37 Komatina P. 2020: 22-23.

38 Stefan Prvovenčani 1999: 20; Komatina P. 2020: 19. Although Stefan does not mention the territories that Nemanja's older brothers obtained at the time of division of the Serbian lands, it can be indirectly concluded that Miroslav was given the area around the Lim river, that Stracimir got Pomoravlje, while for Tihomir, the 
However, probably due to Zavida's death, in the period from before 1146 until 1165, the Grand Župan's throne belonged to the descendants of the earlier Grand Župan Uroš I Uroš II, Beloš and Desa. ${ }^{39}$ The sons of Grand Župan Zavida kept their shares of the land, and it is known that Emperor Manuel I (1143-1180), while resolving the dispute about the grand župan's throne in Serbia in 1155, among other things, designated for other Serbian župans 'their shares, borders and patrimonies, making sure that the assigned parts are inalienable for those who faithfully adhere to what has been determined' ${ }^{40}$ It should also be emphasised that at the time of Emperor Manuel I, there was direct Byzantine rule in Dioclea ${ }^{41}$ unlike in the rest of the Serbian lands where authority was exercised with reliance on the local grand župan and župans.

During the following ten years, Zavida's sons still were not seen as pretenders to the grand župan's throne..$^{42}$ It was only in 1165 , after the deposition of Desa, the youngest son of erstwhile grand župan Uroš I, that the throne was taken over by Zavida's eldest son Tihomir (1165-1166). ${ }^{43}$ It was at that time that the area of Ras, or the 'throne' of Ras came under the authority and in the possession of Zavida's family, of his son, the new grand župan Tihomir. The Byzantine Emperor confirmed him on the grand župan's throne, just as his predecessors. However, Zavida's youngest son, Nemanja, began to pursue autonomous church activity in the 'part of the fatherland' given to him by his father in the $1130 \mathrm{~s} .{ }^{44} \mathrm{As}$ evidenced by Nemanja's biographers, his brothers imprisoned him in a cave near Ras because of this, but he managed to escape and seize the grand župan's throne sometime between April and August 1166. ${ }^{45}$ The Byzantine Emperor Manuel I then backed Nemanja's

eldest brother, there are no data in known sources and there are no implicit indications, but it can be certainly assumed that the 'remaining', i.e. the most important part went to him as the eldest son. In the early $13^{\text {th }}$ century, Tihomir's son župan Stefan Prvoslav held the župa of Budimlja on the upper Lim, Pirivatrić 2011: 53-66, but it seems that the share of his father as the eldest son of the erstwhile grand župan had to be much larger and more important. It should also be borne in mind that grand župan Zavida kept a significant part of the territory for himself - certainly the area around the capital of Ras.

39 That Zavida's sons did not inherit the grand župan's throne, as it was inherited by the sons of Uroš I, can be explained by the fact that the principle of seniority was followed, Komatina P. 2020: 23-32.

40 VIINJ IV 1971: 180-183; Komatina P. 2020: 26-27.

41 The document of Kotor about the consecration of the altar in St Tryphon Church, written on 19 June 1166, unambiguously indicates the solid Byzantine rule in Dioclea - it states that it was issued at the time of imperial rule 'of the most pious and always a victor Manuel', while 'the duke of Dalmatia and Dioclea' was a certain 'kyrios Isanacius" (Isanacius or Isahacius = Isaac?), ('...imperante piissimo et semper triumphatore Hemanuhele, duce exixtente Dalmacie atque Dioclie kyr Isanacio, qui in eadem dedicatione sua gratuita voluntate et benignitate affuit...'), CD II 1904: 102. It is not known at what moment direct rule was established, whether by the merits of Emperor Manuel I (1143-1180) or perhaps already at the time of his predecessor John II (1118-1143).

42 After short-lived Desa's usurpation of the grand župan's throne in 1154-1155, Uroš II kept the position of a grand župan up until 1162. As he was 'insubordinate' to Emperor Manuel I, he was deposed in 1162. Manuel I replaced him first with his younger brother Beloš (1162) and then the youngest brother Desa (1162-1165), Komatina P. 2020: 30-32.

43 Pirivatrić 2015: 158-166; Komatina I. 2020, 40.

44 Nemanja built the monastery of the Most Holy Theotokos and the monastery of St Nicholas, both in Toplica, Stefan Prvovenčani 1999: 24; Sveti Sava 1998: 150; Domentijan 1865: 7-8. About the order of construction of these temples in the mentioned Lives, Komatina I. 2016: 161-162.

45 Pirivatrić 1991: 130-131. 
older brothers militarily with the aim of deposing the disobedient, self-proclaimed grand župan. The newly formed Serbian-Byzantine coalition led by Theodoros Padiates was defeated by Nemanja and his supporters in 1168 near Pantino in Kosovo (near Zvečan), which helped keep Nemanja in power until 1196 and the Diet of Ras, when he decided to abdicate and take monastic vows. ${ }^{46}$ In the first several years, he acted entirely independently, but in 1172 he was forced to subjugate himself to the Byzantine Emperor. ${ }^{47}$

However, immediately upon receiving news of the death of Emperor Manuel in 1180, Nemanja launched an attack on Byzantine territories although he had promised loyalty to the Byzantine Emperor. He was probably prompted by the activity of Manuel's former stepson, Hungarian King Béla III and his struggle for 'patrimony', ${ }^{48}$ and he began the struggle for his 'true dedovina', i.e. Dioclea and Dalmatia, wishing to return the towns which 'the Greek people held with violence', as stated in Stefan's Life. This turned into a severe conflict along the entire Serbian-Byzantine border area. ${ }^{49}$ As Nemanja suffered a crushing defeat at the hands of the Byzantine Empire at the Battle of Morava in 1191, he had to return a large part of the territories conquered during the previous decade, ${ }^{50}$ but out of the conquered areas he retained Dioclea (Zeta) with towns, Pilot, Lab with Lipljan, Dubočica, Reke, Zagrlata, Levče, Lepenica and Belica, as recorded by both Chilandar Charters. At the same time, it should be emphasised that in the Life of his father, his youngest son Sava mentions the same scope of the state as the Charters, but he adds areas in Metohija and Sitnica not present in the Charters and leaves out Lepenica. Sava also explicitly states that all the mentioned areas are Nemanja's dedovina, which in the Charters can be concluded only indirectly. ${ }^{51}$ In contrast, based on Stefan's Life, it is only the territories in the Littoral, i.e. Dioclea and Dalmatia, that are designated as Nemanja's 'true dedovina. ${ }^{52}$ The first sources mentioned state that the entire territory of the Serbian state (Dioclea and Serbia in a narrow sense) is Nemanja's dedovina, while Stefan emphasises

46 Kalić 1970: 196-198; Komatina I. 2016: 188-189.

47 From 1166 to 1172, Nemanja acted independently, only to recognise the supreme power of Byzantine Emperor Manuel I after joining the Venetians in the struggle against the Empire and after the defeat suffered by the coalition. The subjugation to the Byzantine Emperor took place in Constantinople. According to the descriptions of Byzantine authors, on that occasion Nemanja also experienced a personal shame as he was taken tied before the Emperor. About the subjugation of Stefan Nemanja in Choniates' and Kinnamos' work, Vučetić 2013: 493-495; Komatina I. 2020: 41-42.

48 About Béla's patrimony, cf. VIINJ IV 1971: 86, n. 235; Makk 1989: 77-78.

49 He first conquered the towns around the Bojana river, and then went north-west and took Bar, reached Kotor and halted his attack, only to join Hungarian King Béla III; with their forces united, they ravaged Sofia in late 1183 and early 1184. After the success achieved and breaking away from the Hungarian King, Nemanja continued with independent struggles in Pomoravlje, while his brothers continued with struggles in the Littoral. Soon after their futile attack on Dubrovnik, in all probability, the new Byzantine Emperor Isaac II and Nemanja concluded peace in 1186, Komatina I. 2020: 42-43, 46-49.

50 Such conclusion is reached if we apply a critical approach to the data found in the Life of Simeon by Stefan the First-Crowned, both Chilandar Charters and the Life of Simeon by Sava, Komatina I. 2020: 46-52; Komatina I. 2020a: 39-56.

51 Blagojević 2011: 112, states that the expressions from the Chilandar Charters about Nemanja's dedovina etc. clearly suggest that he considered all the joined territories 'the integral parts of Serbia inhabited by the Serbian population'.

52 Komatina I. 2020: 44-48. 
only Dioclea as his 'true dedovina. ${ }^{53}$ This ambiguity was noted by Lj. Kovačević, in his salient treatise on dilemmas concerning Nemanja's origins and activity. Relying on the conclusions of philologist Đ. Daničić, he underlines that the word 'otýiýstvo' should be understood not as 'patrimony', but in the literal sense of the 'fatherland, homeland', which implies Serbia in the narrow sense along with Dioclea, while 'dädina' (dedovina) means 'bona avita', or the patrimony of one's ancestors. ${ }^{54}$ Still, although he gave a correct meaning and use of the word dedovina, Lj. Kovačević believed that Nemanja's ancestors should not be looked for in the Dioclean ruling dynasty of the $11^{\text {th }}$ century. ${ }^{55} \mathrm{~S}$. Ćirković also noted an incongruity in sources regarding the word dedovina, but does not appear to accept explanation of Lj. Kovačević that this place in Stefan's work is a reflection of the fact that after the royal coronation in 1217 he began to boast about his Diocelan origins. Instead, Ćirković emphasises that Stefan obviously only makes a connection with the soil rather than with the rulers of Dioclea, which also largely corresponds to Lj. Kovačević's assumption. ${ }^{56}$

However, the use of the term dedovina seems to suggest an opposite conclusion to the one given by these historians. Namely, dedovina had to be inherited from someone, meaning from ancestors who once possessed it, and it may be concluded that Stefan emphasises the family connection between his father and Dioclea, which, let us remind ourselves, he emphasised back in the first lines of his Life when explaining the issues Nemanja's father had at the time of his birth. By calling Dioclea his father's 'true dedovina,' Stefan underscores his right to inherit it, whereby he does not dispute that the Serbian land in the narrow sense is also his dedovina, as he inherited it from his ancestors as well, but by using the adjective 'true', he further emphasises how old his right to Dioclea is, particularly in the context of the decade-long Byzantine rule which had taken such deep root that Dioclea began to be called 'a Greek domain.' Presenting his father as the legal successor to the erstwhile lords of Dioclea, Stefan unambiguously points out his family connection to them and presents him as their descendant. S. Ćirković rejected such assumption, believing that the fact that 'Nemanja and his brothers' were the uncles of Knez Mihailo, the last ruler of Dioclea, does not allow for linking their family with the old Serbian royal dynasty from Dioclea through a male ancestor. ${ }^{57}$ Nevertheless, it should still be taken into account that until that time, the two branches of the family might have already been sufficiently distant.

When Nemanja withdrew from the Rascian throne at the state Diet of Ras on March 25, 1196, he designated his middle son Stefan as his successor, bypassing his first-born son Vukan. It is believed that the main reason for this decision was the fact that Stefan was the son-in-law of the Byzantine Emperor Alexios III Angelos (1195-1203), as he was married to his daughter Eudokia, ${ }^{58}$ although it is possible that Nemanja's decision was influenced

53 Hilandarska osnivačka povelja 1986: 54-55; Sveti Sava 1998: 148-150; Stefan Prvovenčani 1999: 2, 38; Komatina I. 2020: 44-46; Kovačević 1900: 22, assumes that Nemanja considered Serbia his dedovina, while his son Stefan considered Dioclea his dedovina.

54 Kovačević 1900: 21-23.

55 Kovačević 1900: 22.

56 Ćirković 2000: 26; Kovačević 1955: 291-294.

57 Ćirković 2000: 23.

58 'I left on my throne and entrusted with Christ's given rule my loving son Stefan, the grand župan and sebastokrator, the son-in-law of God's ordained kyrios Alexios, the Greek Emperor'. Hilandarska osnivačka 
by another circumstance as well - the fact that Stefan was, in all probability, Nemanja's first son to be born after he assumed the throne, which could be due to the influence of the Byzantine concept of porphyrogenesis. ${ }^{59}$ Nevertheless, Stefan Nemanja and his sons Stefan and Sava felt the need to justify the decision that the middle son should inherit the throne instead of the eldest one. For instance, in the founding charter of the Chilandar monastery, which he issued two years later as Monk Simeon, Stefan Nemanja emphasises that he had decided to renounce the throne because his country obtained peace and quiet from all around, and he left the throne to his son Stefan, 'the grand župan and sebastokrator, the sonin-law of God's ordained Greek Emperor Alexios,' which is what Stefan reiterates in almost the same way in his charter for the Chilandar monastery, issued around ten years after Simeon's. ${ }^{60}$ However, in the Life of his father, Sava mentions the same thing, but also notes that Nemanja 'wished to and became a kin of the great Greek emperor, God's ordained kyrios Alexios Komnenos, and took his daughter for his virtuous and loving son Stefan, whom he designated as his successor' ${ }^{61}$ When describing the transfer of power from Stefan Nemanja to his son Stefan, Sava also states that Nemanja addressed the Diet with the following words: 'This one (i.e. Stefan) you should have instead of me, he is a good root, to whom I gave life, and it is he whom I place on the throne of the rule given to me by Christ.' All three of them end the description of the transfer of power with the conclusion that Nemanja 'blessed Stefan extraordinarily, just like Isaac blessed Jacob, his son, with every blessing. ${ }^{62}$ Stefan, however, states in the Life he dedicated to his father that he remained to rule after his father on his throne and that his father bestowed on him a blessing, just like God blessed Job's descendants, to rule with lasting success. ${ }^{63}$ Despite emphasizing that the choice of Stefan as successor had been influenced by an important political fact such as familial ties to the ruling Byzantine Emperor, there was still a need to note, for current and future generations, that this choice was neither unlawful nor unjust, but entirely in line with Biblical precedent. ${ }^{64}$

According to the testimony of his youngest son Sava, Nemanja 'blessed' his oldest son Vukan and 'designated him as grand knez, giving him sufficient land.' Sava then ends the

povelja 1986: 55; Stefan Prvovenčani 1999: 8. According to Niketas Choniates, Stefan 'had Eudokia as the co-successor of the paternal rule', VIINJ IV 1971: 165. About the role of Eudokia as the 'co-successor', Pirivatrić 2020: 149-150.

59 Marjanović-Dušanić 1997: 107-110. It was believed in the Byzantine Empire that children born after the

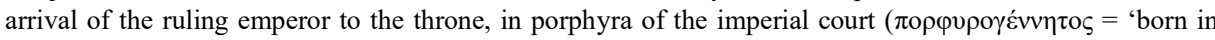
porphyra"), had precedence over their older brothers, born before the royal coronation of their father, cf. Dagron 1996: 61-68.

60 Hilandarska osnivačka povelja 1986: 54-55; Stefan Prvovenčani 1999: 6-8.

61 Sveti Sava 1998: 152, 158.

62 Hilandarska osnivačka povelja 1986: 55; Stefan Prvovenčani 1999:8; Sveti Sava 1998: 158.

63 Stefan Prvovenčani 1999: 50.

64 According to the Book of Genesis, Jacob, owing to the trickery of his mother Rebekah, got (stole) the blessing of his father Isaac, which was intended for his older brother Esau. Isaac soon became aware of his error, but this notwithstanding, he confirmed his blessing for Jacob (1. Moj: 25-34). So, if the great servant of God Isaac blessed his younger, instead of his older son, Stefan Nemanja could do the same. As Stefan writes, Nemanja then extended his blessing on him and his successors, just like God blessed Job's successors, which is an allusion to the Biblical story about righteous Job (Job: 1-2), who is a now a parable for himself. 
apology for Nemanja's decision with a story of fraternal love. ${ }^{65}$ Based on this statement, there is the impression that it was at the mentioned Diet that Nemanja bestowed a part of land on his eldest son; however, the surviving sources suggest that he had bestowed on his sons parts of the fatherland several years before. In Nemanja's charter to the people of Split concerning free trade, most probably issued around 1191-92, it is evident that Vukan had already ruled Dioclea, while Rastko governed Hum. ${ }^{66}$ That Nemanja divided his state (fatherland) before the Diet of Ras is also confirmed by an inscription on the church of St Luke in Kotor from 1195, in which Vukan is mentioned as the ruler of Dioclea with the title of 'King of Dioclea, Dalmatia, Travunia, Toplica and Hvosno'. ${ }^{67}$ Nemanja was still the supreme ruler of all territories since Vukan, along with his own name, also mentions his father, the Grand Župan Nemanja. It is not known which territories belonged to Stefan, or if his father may have intended the throne for him even before the official declaration, encouraged by the fact that the agreement on marriage with Eudokia was concluded even earlier. ${ }^{68}$

It can be concluded that Vukan received a share, or 'a part of the fatherland', even before Nemanja's abdication. Nonetheless, it should be examined why Nemanja decided to cede to his first-born son Dioclea (and Dalmatia), Travunia, Toplica and Hvosno. Were these territories selected randomly, or was there a reason behind it? Considering the assumption presented here concerning the meaning of the term dedovina used by Nemanja as well as his sons Sava and Stefan, it is clear that Nemanja set aside for Vukan Dioclea and Dalmatia, the 'true dedovina', which belonged to his family from old times, and which, in political terms, also included Travunia, then Toplica, the first of the areas he had received as 'a part of the fatherland' from his father, the grand župan Zavida, as well as Hvosno. ${ }^{69}$ Based on this, it may be concluded that these important territories that Nemanja gave to his eldest son were not randomly chosen, and that the oldest and most important parts of the family patrimony were granted to Vukan as the first-born son, regardless of the fact that he was not designated as heir apparent.

Vukan, however, was not satisfied with this status; he was dissatisfied not with the

65 Hilandarska osnivačka povelja 1986: 55; Sveti Sava 1998: 158-162; Stefan Prvovenčani 1999: 8; Kalić 2006 : 193-195; About Vukan's title of a grand knez, cf. Bubalo 2011: 85-87.

66 In Nemanja's charter to the people of Split it is stated that they could freely come to his land 'and the land of Hum of his son Rastko and to Zeta of his son Vuk", Zbornik 2011: 63-64; Tri povelje: 69-70. Nemanja entrusted the land of Hum to his youngest son Rastko for governance certainly after Nemanja's brother Miroslav withdrew from Hum, Ugovor kneza Miroslava 2012: 11-23. Along with the area around the Lim river, at some point Miroslav also gained Zahumlje (the area of Hum), Marković 2012: 21-40, which was granted to him probably when Desa became the grand župan in 1162, Komatina P. 2020: 29.

67 Pisci srednjovjekovnog latiniteta 1996: 160; Natpis na crkvi 1997: 23-32.

68 Pirivatrić 2015a: 49-50; Pirivatrić 2020: 139-155.

69 Neither of the Chilandar Charters states that Stefan Nemanja captured Hvosno, Hilandarska osnivačka povelja 1986: 54; Stefan Prvovenčani 1999: 2, only Sava's Life states that Nemanja seized it 'from the Greek land', Sveti Sava 1998: 148, 150. Sava, in fact, adds the župas that Nemanja does not mention to have seized at all, which may imply that the area of Metohija belonged to the Serbian state even before, Komatina I. 2020: 52, n. 60. However, it should be borne in mind that Hvosno did not belong to Nemanja before he became the grand župan, but it could have belonged to Tihomir, Nemanja's eldest brother, about whose share of land we have no data; after his death, it belonged to new grand župan Nemanja and his descendants. If Nemanja's father, on the occasion of the division of shares among his sons, ceded Hvosno to his eldest son, this could also explain the fact that, later, Nemanja assigned it for his own eldest son. 
choice of lands granted to him, but with the fact that he did not inherit the throne of Rascia. Three documents from Kotor from 1197, 1199 and 1200 were compiled only in his name as the 'King of Dioclea, Dalmatia, Travunia and Toplica', without any mention of Grand Župan Stefan, unlike the inscription in Kotor from 1195 where, in addition to King Vukan, Grand Župan Nemanja is mentioned as well. ${ }^{70}$ His aspiration to the grand župan's throne brought about a civil war. The conflict between Vukan and Stefan is believed to have begun in around 1201/1202 and that Vukan defeated Stefan in 1202 and seized the grand župan's throne, but the war eventually ended in 1204/1205 in Stefan's favour. ${ }^{71}$ After the defeat, Vukan lost the grand župan's throne, but he kept the domains previously granted to him, despite the fact that he violated the oath of loyalty to his sovereign, Grand Župan Stefan. His son Đorđe succeeded him as the governor of Dioclea in 1207/1208. ${ }^{72}$ However, when Đorđe rose up against Grand Župan Stefan and swore fealty to the Venetian Doge in July 1208, Stefan, removed him from the position of the ruler of Dioclea and deprived him of his territories due to treason, ${ }^{73}$ and shortly after donated the estates in Hvosno and Zeta, the earstwhile Vukan's territories, to the Chilandar monastery. ${ }^{74}$ Furthermore, Stefan later entrusted his heir apparent, his first-born son Radoslav, with the governance of Dioclea. ${ }^{75}$ There is the impression that the attitude towards Dioclea and its status within the the house of Nemanjić was always of particular importance. When King Stefan Vladislav lost his throne in 1242/1243, his brother and successor to the throne, Stefan Uroš I, ceded Dioclea to him after a reconciliation, possibly because he was his older brother, and in all probability, Vladislav ruled Dioclea until his death. King Dragutin, who deposed his father Uroš in 1276 after he refused to entrust him with governance of any part of the country during his life, ceded Dioclea to his mother Queen Helen of Anjou upon assuming the throne. King Milutin also entrusted Dioclea to his first-born son, Stefan (Dečanski), who then entrusted it to his first-born son and successor, Stefan Dušan. The custom to entrust the governance of Dioclea (Zeta) to the first-born son or elder brother could then have its roots in the perception among members of the Nemanjić dynasty of this part of the Serbian land as being their 'true dedovina'.

There are clear similarities between the last and the first two examples. The throne was left to the second-born son, who was, for some reason, given precedence over his elder brother. As greater affinity on the part of the father toward the second son is mentioned in the Spanish and English cases, in the Serbian case there is an 'extraordinary blessing' which the father bestows on his second-born son, but family ties to the Byzantine Emperor are also emphasised as the main reason behind why he inherited the throne. Just as in the two western European cases, the eldest son was displeased, as he wished, as the eldest one, to be the

\footnotetext{
CD II 1904: 287, 324, 341-342; Gyug 2016: 557, 565, 567; Bubalo 2011: 80-81; Komatina 2016: 222.

Stanojević 1933: 93-101; Porčić 2020: 76-78, n. 43. The well-known inscription of monk Simeon at the end of Vukan's Gospel remained from the time of Vukan's short-lived rule in Serbia. The Gospel was named as Vukan's because it was completed during the rule of grand župan Vukan and is dedicated to him, Stari srpski zapisi i natpisi I 1902: 4; Trifunović 2001: 69-74, 77-83; Komatina 2016: 251-252.

72 Komatina I. 2020b: 24-33.

73 Porčić, Isailović 2019: 207-208. It is possible that Đorđe maintained rule in only one part of Dioclea, Bubalo 2009: 216; Komatina I. 2020b: 30.

74 About the estates in Hvosno that Stefan donated to Chilandar, Živojinović 2020: 83-87 (see the map on p. 96), as well as about the estates in Zeta, Ćirković 1998: 144-152.

75 Bubalo 2009: 201-227.
} 
father's sole successor and to rule the entire state, i.e. to assume the ruler's throne. In all of these cases, the elder brother went to war against his brother, but was eventually defeated and forced to accept his father's bequest. In the first two cases, the share of the first-born son included the family patrimony of his father, which had already been designated for him during his father's life. This was also the case with Serbian prince Vukan, to whom his father, because he was the eldest son, assigned the oldest domains of his family - those of his ancestors, his brothers, and of his own share - already during his life. Because of their obvious parallels, the three examples presented here were chosen as an illustration of this phenomenon, but there are undoubtedly more similar examples in the tumultuous dynastic history of medieval Europe. ${ }^{76}$ In addition to the perception of treason as the most grievious violation of the feudal order, which implies the loss of a feudal domain as the most serious punishment, and morganatic marriage as an unacceptable relationship between people of different social ranks, ${ }^{77}$ the concept of family patrimony as an inviolable legacy of the firstborn son was another phenomenon known in the feudal society of medieval Europe which could also be recognised in Serbia at the time, a country with an undeniably Byzantine culture, but also of a social order that largely differed from that of the Byzantine Empire. ${ }^{78}$

\section{REFERENCES:}

Primary Sources:

Domentijan, Život Sveoga Simeuna i Svetoga Save (prir. Daničić, Đ.), Beograd: Državna štamparija, 1865. (Serbian Cyrillic)

Tri povelje iz ispisa Ivana Lučića (prir. M. Dinić), Zbornik Filozofskog fakulteta u Beogradu, 3, 1955, 69-94. (Serbian Cyrillic)

Chronicon Compostellanum (ed. Falque, E.), Habis, 14, 1983, 73-83.

Sveti Sava, Sabrana dela (prir. i prev. Jovanović, T.), Beograd: Srpska književna zadruga, 1998. (Serbian Cyrillic)

Stefan Prvovenčani, Sabrana dela (prir. Juhas-Georgievska, Lj. i Jovanović, T.), Beograd: Srpska književna zadruga, 1999. (Serbian Cyrillic)

Orderici Vitalis Angligenae coenobii Uticensis monachi, Historiae Ecclesiasticae libri tredecim I-V (ed. Le Prevost), Parisiis: Julius Renouard et Socii, 1838-1855.

Zbornik srednjovekovnih ćiriličkih povelja i pisama Srbije, Bosne i Dubrovnika, knj. I, 1186-1321 (prir. Mošin, V. Ćirković, S. i Sindik, D.), Beograd: Istorijski institut, 2011. (Serbian Cyrillic)

Vizantijski izvori za istoriju naroda Jugoslavije IV (ur. Ostrogorski, G. i Barišić, F.), Beograd: Vizantološki institut SANU, 1971. (Serbian Cyrillic)

Ugovor kneza Miroslava i Dubrovčana (prir. Ravić, I.), Stari srpski arhiv, 11, 2012, 11-23. (Serbian Cyrillic)

76 It is known, for instance, that Holy Roman Emperor Frederick Barbarossa (1152-1190), at the imperial diet in Bamberg in 1169, chose as heir apparent his second son Henry, who was later crowned King of the Romans. He granted to his older son, first-born Frederick (V), the title of the Duke of Swabia, the patrimonial land of the Hohenstaufen dynasty, although the emperor practically always had it at his disposal and could grant it to his sons and relatives, Baaken 1968: 46-78. Still, it should be borne in mind that the imperial status in the Holy Roman Empire was not hereditary.

77 Komatina I. 2020b: 21-44; Komatina P. 2020a: 45-59.

78 Krsmanović, Maksimović 2016: 41-55. 
Crónica del obispo don Pelayo (ed. Sánchez Alonso, B.), Madrid: Sucesores de Hernando, 1924.

Historia silense (ed. Santos Coco, F.), Madrid: Sucesores de Rivanedeyra, 1921.

Pisci srednjovijekovnog latiniteta (prir. Sindik, D. i Tomović, G.), Cetinje: Obod 1996. (Serbian Cyrillic)

Codex diplomaticus regni Croatiae, Dalmatiae et Slavoniae II (ed. Smičiklas, T.), Zagreb: Tisak Dioničarske tiskare, 1904.

Stari srpski zapisi i natpisi I (prir. Stojanović, Lj.), Beograd: Državna štamparija Kraljevine Srbije, 1902. (Serbian Cyrillic)

Natpis na crkvi Sv. Luke u Kotoru (prir. Tomović, G.), u: V. Korać (ur.), Crkva Sv. Luke kroz vjekove, Kotor: Srpska pravoslavna crkvena opština, 1997, 23-33. (Serbian Cyrillic)

Hilandarska osnivačka povelja Svetoga Simeona i Svetoga Save (prir. Trifunović, Đ., Bjelogrlić, V. i Brajović, I.), u: episkop žički Stefan, A. Jevtić, D. Kašić (ur.), Osam vekova manastira Studenice, Beograd: Sveti arhijerejski Sinod SPC, 1986, 49-60. (Serbian Cyrillic)

Secondary works:

Aird, W. Robert Curthose, Duke of Normandy, c. 1050-1134, Woodbridge: The Boydell Press, 2008.

Alonso Álvarez, R. 'La obra histórica del obispo Pelayo de Oviedo (1089-1153) y su relación con la Historia legionensis (llamada silensis)', e-Spania 14 (décembre 2012) Publicado el 20 noviembre 2013, consultado el 28 abril 2021. URL: http://journals.openedition.org/espania/21586; DOI: https://doi.org/10.4000/e-spania.21586

Baaken, G. 'Die Altersfolge der Söhne Friedrich Barbarossas und die Königserhebung Heinrichs VI', Deutsches Archiv für Erforschung des Mittelalters, 24, 1968, 46-78.

Bates, D. William the Conqueror, New Haven/London: Yale University Press, 2016.

Bergqvist, K. 'The Vindication of Sancho II in the Crónica de Castile: Political Identity and Historiographical Reinvention in Medieval Castilian Chronicles', in: E. Kooper and S. Levelt (eds.), The Medieval Chronicle 11, Leiden/Boston: Brill, 2018, 64-86.

Blagojević, M. Srpska državenost u srednjem veku, Beograd: Srpska književna zadruga, 2011. (Serbian Cyrillic)

Blok, M. Feudalno društvo, Sremski Karlovci - Novi Sad: Izdavačka knjižnica Zorana Stojanovića, 2012. (Serbian Cyrilic)

Bubalo, Đ. 'Da li su kralj Stefan Prvovenčani i njegov sin Radoslav bili savladari?', Zbornik radova Vizantološkog instituta, 46, 2009, 201-229. (Serbian Cyrillic)

. 'Još jednom o godini smrti kralja Stefana Prvovenčanog', u: A. Rastović, I. Komatina (ur.), Stefan Prvovenčani i njegovo doba, Beograd: Istorijski institut, 2020, 99-118. (Serbian Cyrillic) 'Titule Vukana Nemanjića i tradicija dukljanskog kraljevstva', u: B. Todić (ur.), Đurđevi Stupovi i Budimljanska eparhija, Berane/Beograd: Episkopija Budimljansko-nikšićka, Institut za istoriju umetnosti Filozofskog fakulteta u beogradu, Polimski muzej Berane, Institut za teološka istraživanja, 2011, 79-93. (Serbian Cyrillic)

Carpenter, D. The Struggle for Mastery. Britain 1066-1284, London: Penguin Books, 2004.

Carriedo Tejedo, M. 'La coronación de Alfonso VI en León (3 de enero de 1066)', Tierras de León: Revista de la Diputación Provincial, 41/117, 2003, 13-30.

Ćirković, S. 'Hilandarski metoh u Zeti', Hilandarski zbornik, 10, 1998, 145-152. (Serbian Cyrillic) . 'Preci Nemanjini i njihova postojbina', u: J. Kalić (ur.), Stefan Nemanja - Sveti Simeon Mirotocivi. Istorija i predanje, Beograd: Srpska akademija nauka i umetnosti, 2000, 21-28. (Serbian Cyrillic)

Dagron, G. Empereur et prêtre. Étude sur le 'césaropapisme’ byzantin. Paris: Gallimard, 1996.

Davis, R. H. C. 'William of Jumiège, Robert Curthose and the Norman succession', English Historical 
Review, 95, 1980, 597-606.

English, B. 'William the Conqueror and the Anglo-Norman Succession', Historical Research, 64, 1991, 221-236.

Garnett, G. Conquered England. Kingship, Succession, and Tenure, 1066-1166, Oxford: Oxford University Press, 2007.

Gonzalez Minguez, C. 'El Proyecto Politico de Sancho II de Castile 1065-1072', Publicaciones de la Institución Tello Téllez de Meneses, 73, 2002, 77-98.

Gyug, R. Liturgy and Law in a Dalmatian City. The Bishop's Book of Kotor (Sankt-Peterburg, BRAN, F. no. 200), Totonto: Pontifical Institute of Medieval Studies, 2016.

Holt, J. C. 'Politics and property in early medieval England', Past and Present, 57, 1972, 3-52.

Kalić, J. 'Srpski državni sabori u Rasu', u: J. Kalić, Evropa i Srbi. Srednji vek, Beograd: Istorijski institut, 2006, 185-195. (Serbian Cyrillic)

. 'Srpsko-vizantijski sukob 1168. godine', Zbornik Filozofskog fakulteta u Beogradu 11/1, 1970, 193-204. (Serbian Cyrillic)

Komatina, I. 'I obnovi svoju dedovinu i bolje je utvrdi - Stefan Nemanja i Stefan Prvovenčani i uobličavanje srpske državnosti', u: A. Rastović, I. Komatina (ur.), Stefan Prvovenčani i njegovo doba, Beograd: Istorijski institut, 2020, 37-61. (Serbian Cyrillic)

. Crkva i država u srpskim zemljama od XI do XIII veka, Beograd: Istorijski institut, 2016. (Serbian Cyrillic)

'Nekoliko zapažanja o bici na Moravi', Istorijski časopis, 69, 2020a, 39-60. (Serbian Cyrillic)

'Neki primeri izdaje u Srbiji XIII veka', Zbornik radova Vizantološkog instituta, 57, 2020b, 21-44. (Serbian Cyrillic)

Komatina, P. 'Žitije Sv. Simeona od Stefana Nemanjića kao izvor za hronologiju promena na velikožupanskom prestolu', u: A. Rastović, I. Komatina (ur.), Stefan Prvovenčani i njegovo doba, Beograd: Istorijski institut, 2020, 17-35. (Serbian Cyrillic)

. 'O prvom braku kralja Milutina', Zbornik radova Vizantološkog instituta, 57, 2020a, 45-59. (Serbian Cyrillic)

Kovačević, J. 'Tradicija o dukljanskom kraljevstvu kod Nemanjića', Istorijski časopis, 5, 1954-1955, 291-294. (Serbian Cyrillic)

Kovačević, Lj. 'Nekoliko pitanja o Stefanu Nemanji: prilog kritici izvora za srpsku istoriju XII veka', Glas Srpske kraljevske akademije, 58, 1900, 1-107. (Serbian Cyrillic)

Krsmanović B. and Maksimović Lj., 'Byzantium in Serbia - Serbian authenticity and the Byzantine influence', in: D. Vojvodić and D. Popović (eds.) Byzantine Heritage and Serbian Art II. Sacral Art of the Serbian Lands in the Middle Ages, Belgrade: The Serbian National Committee of Byzantine Studies, P. E. Službeni glasnik, Institute for Byzantine Studies, Serbian Academy of Sciences and Arts, 2016, 41-55.

Le Patourel, J. 'The Norman succession, 996-1135', English Historical Review, 86, 1971, 225-250.

Linehan, P. Spain 1157-1300. A Partible Inheritance, Malden, MA: Blackwell Publishing, 2008.

Makk, F. The Arpáds and the Comneni. Political Relations between Hungary and Byzantium in the $12^{\text {th }}$ Century, Budapest: Akadémiai Kiadó, 1989.

Marjanović-Dušanić, S. Vladarska ideologija Nemanjića. Diplomatička studija, Beograd: Srpska književna zadruga, Sveti Arhijerejski Sinod Srpske pravoslavne crkve, Clio, 1997. (Serbian Cyrillic)

Marković, M. 'O ktitorskom natpisu kneza Miroslava u crkvi Svetog Petra na Limu', Zograf, 36, 2012, 21-46. (Serbian Cyrillic)

Martínez Díez, G. Alfonso VI. Rey del Cid, conquistador de Toledo, Madrid: Temas de Hoy, 2003. . El Condado de Castilla (711-1038). La historia frente a la leyenda I-II, Valladolid: Marcial Pons Historia, 2005. 
. Sancho III el Mayor Rey de Pamplona, Rex Ibericus, Madrid: Marcial Pons Historia, 2007.

Pérez de Urbel, J. 'La división del reino por Sancho el Mayor', Hispania: Revista española de historia, 14/54, 1954, 3-26.

Pirivatrić, S. 'Prilog hronologiji početka Nemanjine vlasti', Zbornik radova Vizantološkog instituta, 29-30, 1991, 125-136. (Serbian Cyrillic)

. 'O Stefanu Prvoslavu, ktitoru crkve svetog Georgija u Budimlji', u: B. Todić (ur.), Đurđevi Stupovi i Budimljanska eparhija, Berane/Beograd: Episkopija Budimljansko-nikšićka, Institut za istoriju umetnosti Filozofskog fakulteta u beogradu, Polimski muzej Berane, Institut za teološka istraživanja, 2011, 53-67. (Serbian Cyrillic)

'Byzantine-Hungarian relations in 1162-1167 and the desposition of Serbian grand župan Desa', in: E. Juhász (Hrsg.), Byzanz und das Abendland III. Studia Byzantino-Occidentalia, Budapest: Eötvös-József-Collegium, 2015, 159-166.

- 'Hronologija i istorijski kontekst podizanja manastira Studenice. Prilog istraživanju problema', Zograf, 39, 2015a, 47-56. (Serbian Cyrillic)

. 'Brak Stefana Nemanjića i Evdokije Anđeline Komnine. Hronologija i istorijski kontekst ugovaranja i raksidanja jednog dinastičkog saveza', u: A. Rastović, I. Komatina (ur.), Stefan Prvovenčani i njegovo doba, Beograd: Istorijski institut, 2020, 139-158. (Serbian Cyrillic)

Porčić, N. 'Vukan Nemanjić - krunisani i miropomazani kralj?, u: A. Rastović, I. Komatina (ur.), Stefan Prvovenčani i njegovo doba, Beograd: Istorijski institut, 2020, 63-82. (Serbian Cyrillic)

Porčić, N. i Isailović, N. Dokumenti srednjovekovnih vladara Srbije $i$ Bosne u venecijanskim zbirkama, Beograd: Arhiv Srbije, 2019. (Serbian Cyrillic)

Reilly, B. F. The Kingdom of León-Castile under King Alfonso VI, 1065-1109, Princeton: Princeton University Press, 1988.

Sánchez Candeira, A. Castile y León en el siglo XI. Estudio del reinado de Fernando I, Madrid: Real Academia de la Historia, 1999.

Stanojević, S. 'Hronologija borbe između Stevana i Vukana', Glas Srpske kraljevske akademije, 153, 1933, 93-101. (Serbian Cyrillic)

Trifunović, Đ. 'Zapis starca Simeona na Vukanovom jevanđelju', Prilozi za književnost, jezik, istoriju i folklor, 67, 2001, 63-85. (Serbian Cyrillic)

Ubieto Arteta, A. 'Estudios en torno a la división del Reino por Sancho el Mayor de Navarra', Príncipe de Viana, 21/78-79, 1960, 5-56.

Vivancos Gómez, M. Reinado y diplomas de Sancho II de Castile y León, Madrid: Ediciones de La Ergástula, 2014.

Vučetić, M. M. 'Ritual potčinjavanja Stefana Nemanje caru Manojlu I Komninu', Zbornik radova Vizantološkog instituta, 50/1, 2013, 493-503. (Serbian Cyrillic)

Živojinović, M. 'Veliki župan Stefan Nemanjić - metoh u Hvosnu', u: A. Rastović, I. Komatina (ur.), Stefan Prvovenčani i njegovo doba, Beograd: Istorijski institut, 2020, 83-98. (Serbian Cyrillic) 
ИВАНА КОМАТИНА

Историјски институт, Београд

ПРЕДРАГ КОМАТИНА

Византолошки институт САНУ

\title{
ПОРОДИЧНА БАШТИНА И НАСЛЕЪЕ ПРВОРОЪЕНОГ СИНА. ПРИМЕРИ ИЗ ЕВРОПСКИХ МОНАРХИЈА У ХІ-ХІІ ВЕКУ
}

\begin{abstract}
Резиме
У три различите монархије Западне и Југоисточне Европе током XI и у XII веку да се уочити веома занимљив однос према породочиној баштини. Наиме, она представља наследство предака односно дедовину и по правилу се додељује најстаријем сину, без обзира на то да ли је он уз то наследник престола или не. У средњовековној Шпанији краљ Леона и Кастиље Фернандо I (1037-1065) свој престо је оставио свом средњем сину Алфосну VI и поверио му Леонско краљевство, док је најстаријем сину Санчу II оставио Кастиљу. Незадовљан таквом очевом одлуком, Санчо II отпочео је дугогодишњи грађански рат, али су његови успеси били кратког даха будући да је Алфонсо VI успео да под својом влашћу обједини Леон, Кастиљу и Галицију. Сличан пример сусрећемо и у средњовековној Енглеској када је краљ Енглеске и војвода Нормадије Виљем I Освајач (1066-1087) такође за наследника одредио свог средњег сина Виљема II, док је старијем сину Роберту због лоше нарави препустио Војводство Нормандију. Незадовољан таквом очевом одлуком, Роберт је уз део норманских барона покушао да потисне свог брата, али је његова побуна осуђена на пропаст, те је на крају прихватио додељени му положај војводе Нормандије. Крајем XII века владар Србије велики жупан Стефан Немања (1166-1196) препустио је престо свом средњем сину Стефану, а не прворођеном Вукану, вероватно због чињенице да је Стефан био зет тадашњег византијског цара. Међутим, он је синовима и пре силаска са престола препустио делове отачаства. Зна се да је Вукану припала истинита дедовина Дукља и Далмација, те Травунија, Топлица и Хвосно, поседи које су од давнина поседовали њихови преци или сам Немања. Као у претходна два случаја најстарији син био је незадовољан очевом одлуком те је тако отпочео вишегодишњи рат између Стефана и Вукана, који се ипак завршио Стефановом победом. Вукан се пак морао задовољити додељеном земљом. Осим одлуке да се престо остави средњем сину, што је може се рећи коинциденција у сва три поменута случаја, чињеница да се породична баштина увек остављала најстаријем сину указује да му се то право није могло ускратити као право наслеђа престола. Може се рећи да је схватање о породичној баштини као неотуђивом праву прворођеног сина у средњовековној Европи један од важних елемената разумевања и спознавања феудалног друштва.
\end{abstract}

Кључне речи: породична баштина, дедовина, Фернандо I, Виљем I Освајач, Стефан Немања, средњовековна монархија, феудално друштво. 